\title{
KONVERGENSI DAN FAKTOR-FAKTOR YANG MEMPENGARUHI DISPARITAS WILAYAH KABUPATEN/KOTA DI INDONESIA
}

\author{
Masfufah \\ Mahasiswa Pascasarjana Mayor Ilmu Perencanaan Pembangunan Wilayah dan Perdesaan, E-mail: \\ masfufah@bps.go.id
}

\begin{abstract}
ABSTRAKSI. Pembangunan wilayah merupakan sub sistem dari pembangunan koridor ekonomi dan provinsi, juga merupakan bagian yang tak dapat dipisahkan dari pembangunan nasional. Implikasi dari pembangunan ekonomi pada setiap tingkat kabupaten telah memberikan prestasi yang berbeda. Implikasi dari kebijakan desentralisasi fiskal sejak tahun 2001, memberikan peran penting kepada pemerintah daerah dalam pertumbuhan wilayah. Tujuan dari penelitian ini adalah untuk menganalisis dinamika disparitas wilayah dan pembangunan infrastruktur, untuk menguji konvergensi wilayah dan membandingkan fenomena tingkat konvergensi antar wilayah koridor eonomi di Indonesia dikaji dari pendekatan pendapatan Produk Domestik Regional Bruto (PDRB) dan pendekatan pengeluaran rumah tangga, dan untuk menganalisis faktor-faktor yang memperngaruhi disparitas wilayah antar koridor ekonomi di Indonesia untuk periode lima tahun yaitu 2006-2010. Hasil analisis daripenelitian ini menunjukkan bahwa dengan pendekatan PDRB, tidak terjadi konvergensi pendapatan tingkat kabupaten/ kota di Indonesia, sedangkan jika menggunakan pendekatan pengeluaran rumah tangga dengan tehnik estimasi FD-GMM, terjadi proses konvergensi. Selanjutnya, terjadi konvergensi di setiap koridor ekonomi, baik dengan pendekatan PDRB maupun pengeluaran rumah tangga. Konvergensi tercepat terjadi di koridor ekonomi Jawa dengan pendekatan pengeluaran rumah tangga.

Kata kunci: Konvergensi, Ketimpangan, Data Panel FD-GMM
\end{abstract}

\section{CONVERGENCE AND THE FACTORS THAT INFLUENCE REGIONAL INEQUALITY OF DISTRICT LEVEL IN INDONESIA}

\begin{abstract}
Areas development is a sub system of economic corridors and province development, also as part of national development that could not be separated. The implication of economic development at each district level has been gave different achievement. The Implication of fiscal decentralization policy on 2001, gave an important roles to the region government on areas growth. Aims of this research are to analyze dynamics of areas disparity and facilities development, to examine the income convergence by Gross Regional Domestic Product (GRDP) and household expenditures of district level areas and comparing between economic corridor in Indonesia, and to analyze the influence factors of areas disparity between economic corridor in Indonesia for five years period on 2006-2010. The conclusion of analysis result shows when used GRDP, there were no income convergence of district level in Indonesia, while when used household expenditures by FD-GMM estimation technique, there were a number of convergence process. Further, there were convergences in every economic corridor, both with GRDP or household expenditures. The fastest convergence exists at Java Economic Corridor by household expenditures.
\end{abstract}

Keywords : Convergence, Inequality, FD-GMM Panel Data

\section{PENDAHULUAN}

Pertumbuhan ekonomi suatu negara menentukan standar hidup negara tersebut. Pertumbuhan ekonomi yang tinggi dalam pelaksanaan pembangunan merupakan salah satu sasaranbagi negara-negara berkembang. Perkembangan perekonomian yang dicapai bangsa Indonesia sampai saat ini ternyata masih harus menghadapi permasalahan yang mungkin juga dialami negara lain khususnya negara sedang berkembang. Realitas pembangunan ekonomi di Indonesia yang diakibatkan oleh adanya perbedaan laju pertumbuhan adalah terciptanya disparitas antar wilayah. Hal tersebut salah satunya disebabkan oleh perbedaan faktor endownment dari masing-masing wilayah. Data BPS 2007 mengenai PDRB dan laju pertumbuhan ekonomi seluruh provinsi menunjukkan bahwa terjadi pemusatan produksi barang dan jasa di Pulau Jawa yang luasnya hanya 7 persen dari luas Indonesia ini mendominasi sekitar 60,2 persen dari seluruh PDRB. Sedangkan provinsi di Sumatera 
menguasai 22,98 persen, Kalimantan $(9,13$ persen, Sulawesi (4,09 persen), dan provinsi di Nusa Tenggara, Maluku, dan Papua hanya 3,61 persen. Sementara itu, rata-rata laju pertumbuhan ekonomi provinsi di Jawa dan Bali sebesar 6,17 persen, Sumatera (4,96 persen), Kalimantan (3,14 persen), Sulawesi $(6,88$ persen), provinsi di Nusa Tenggara, Maluku, dan Papua (5,04 persen). Kecenderungan persebaran penguasaan PDRB dan laju pertumbuhan yang tidak sama akan menyebabkan timpangnya pembangunan antar wilayah.

Pola perubahan struktur perekonomian di Indonesia dilihat dari share sektor manufaktur lebih tinggi dibandingkan pertanian dan jasa yaitu sekitar 63 persen dan 21 persen di tahun 2009, namun share tenaga kerja sektor pertanian masih lebih tinggi dibandingkan manufaktur yaitu sekitar 40 persen. Hal ini mengindikasikan adanya disparitas antar wilayah di Indonesia.

Tingkat disparitas Indonesia dari tahun 1991-2007 cukup besar, yaitu berada pada kisaran 0,6 sampai 0,8. Berdasarkan hal tersebut, dapat diartikan bahwa antar provinsi di Indonesia terjadi disparitas pendapatan yang cukup besar. Hal ini tidak terlepas dari perbedaan kemampuan fiskal tiap daerah yang berimplikasi terhadap nilai tambah bruto (PDRB) dalam perekonomian antar wilayah. Pada tahun 1991-2007, indeks Williamson terbesar terjadi pada tahun 2001 dan 2005 yaitu 0,79 . Akan tetapi peningkatan yang terbesar terjadi pada tahun 2001, dimana pada tahun tersebut mulai diberlakukan Undang-undang Otonomi Daerah. Dengan adanya otonomi daerah, setiap wilayah mempunyai kewenangan untuk mengatur daerahnya masing-masing.

Fenomena disparitas antar wilayah yang terjadi, diantaranya dapat disebabkan oleh perbedaan ketersediaan fasilitas infrastruktur (pendidikan, kesehatan, jalan, listrik, air bersih, dan telepon). Infrastruktur merupakan roda penggerak pertumbuhan ekonomi. Keberadaan infrastruktur akan men-dorong terjadinya peningkatan produk-tivitas bagi faktor-faktor produksi, dan sebaliknya apabila mengabaikannya akan menurunkan produktivitas. Dalam implementasi MP3EI ${ }^{1}$ (Masterplan Percepatan dan Perluasan

Peluncuran Masterplan Percepatan dan Perluasan Pembangunan Ekonomi Indonesia (MP3EI) 2011-2025 oleh Presiden Indonesia Susilo Bambang Yudhoyono pada tanggal $27 \mathrm{Mei}$ 2011. Tujuan awal dilakukannya MP3EI adalah untuk mencapai aspirasi Indonesia 2025, yaitu PDB sekitar USD 4,3 tri-
Pembangunan Ekonomi Indonesia) dilakukan untuk mengembangkan 8 program utama yang terdiri dari 22 kegiatan ekonomi utama sesuai dengan potensi dan nilai strategis kegiatan utama tersebut di koridor yang bersangkutan. Dimana salah satu strateginya diantaranya adalah mengembangkan potensi ekonomi wilayah di 6 koridor ekonomi yaitu koridor ekonomi Sumatera, Jawa, Kalimantan, Sulawesi, Bali, Nusa Tenggara, dan Papua Kep. Maluku dimana masing koridor ekonomi tersebut diposisikan strategi yang berbedabeda.

Beranjak dari fenomena tersebut, bahwa karakteristik potensi wilayah koridor, baik yang bersifat alami maupun buatan merupakan salah satu unsur yang menarik dikaji dalam kaitannya dengan upaya pengurangan disparitas pembangunan antar wilayah koridor ekonomi dankabupaten/kotayang ada. Dengan demikian diharapkam akan tercipta pemerataan (equity), pertumbuhan (efficiency), dan keberlanjutan (sustainability) dalam pembangunan wilayah.

Dinamika pendapatan antar wilayah selama ini dianalisis dengan menggunakan data PDRB yang menunjukkan potensi wilayah dalam proses produksi. Data ini kurang dapat mempresentasikan kemampuan masyarakatnya dalam mencapai kesejahteraan. Analisis konvergensi wilayah berdasarkan data tersebut perlu dibandingkan dengan melihat pendapatan masyarakat, yang diproksi dengan menggunakan pendekatan pengeluaran rumah tangga.

Secara umum penelitian ini bertujuan menganalisis konvergensi dan faktor-faktor yang mempengaruhi diasparitas antar wilayah koridor ekonomi di Indonesia. Secara lebih rinci, penelitian ini bertujuan untuk:

1. Menganalisis dinamika disparitas pendapatan dan pembangunan infrastruktur antar wilayah koridor ekonomi di Indonesia.

2. Menguji konvergensi wilayah dan membandingkan fenomena tingkat konvergensi antar wilayah koridor ekonomi di Indonesia dikaji dari pendekatan pendapatan wilayah dengan

liun dan menjadi negara dengan PDB terbesar ke-9 di dunia. Untuk mewujudkan hal tersebut, sekitar $82 \%$ atau USD 3,5 triliun akan ditargetkan sebagai kontribusi PDB dari koridor ekonomi sebagai bagian dari transformasi ekonomi. Dokumen MP3EI tidak menggantikan RPJMN 2005-2025 (UU No. 17 Tahun 2007) dan RPJMN 2005-2015 (Peraturan Presiden No.5 Tahun 2010). Seluruh program regular pemerintah yang tidak dicakup dalam MP3EI berjalan seperti biasa sesuai dengan perencanaan. Program pengembangan MP3EI mencakup pembangunan di seluruh tanah air. 
pendekatan PDRB dan pendekatan pengeluaran rumahtangga.

3. Menganalisis faktor-faktor yang mempengaruhi disparitas wilayah antar koridor ekonomi di Indonesia.

Tabel 1. Matriks Pendekatan Penelitian
Uraian mengenai tujuan penelitian, metode analisis yang digunakan, serta variabel yang digunakan dalam penelitian ini dijelaskan pada Tabel 1.

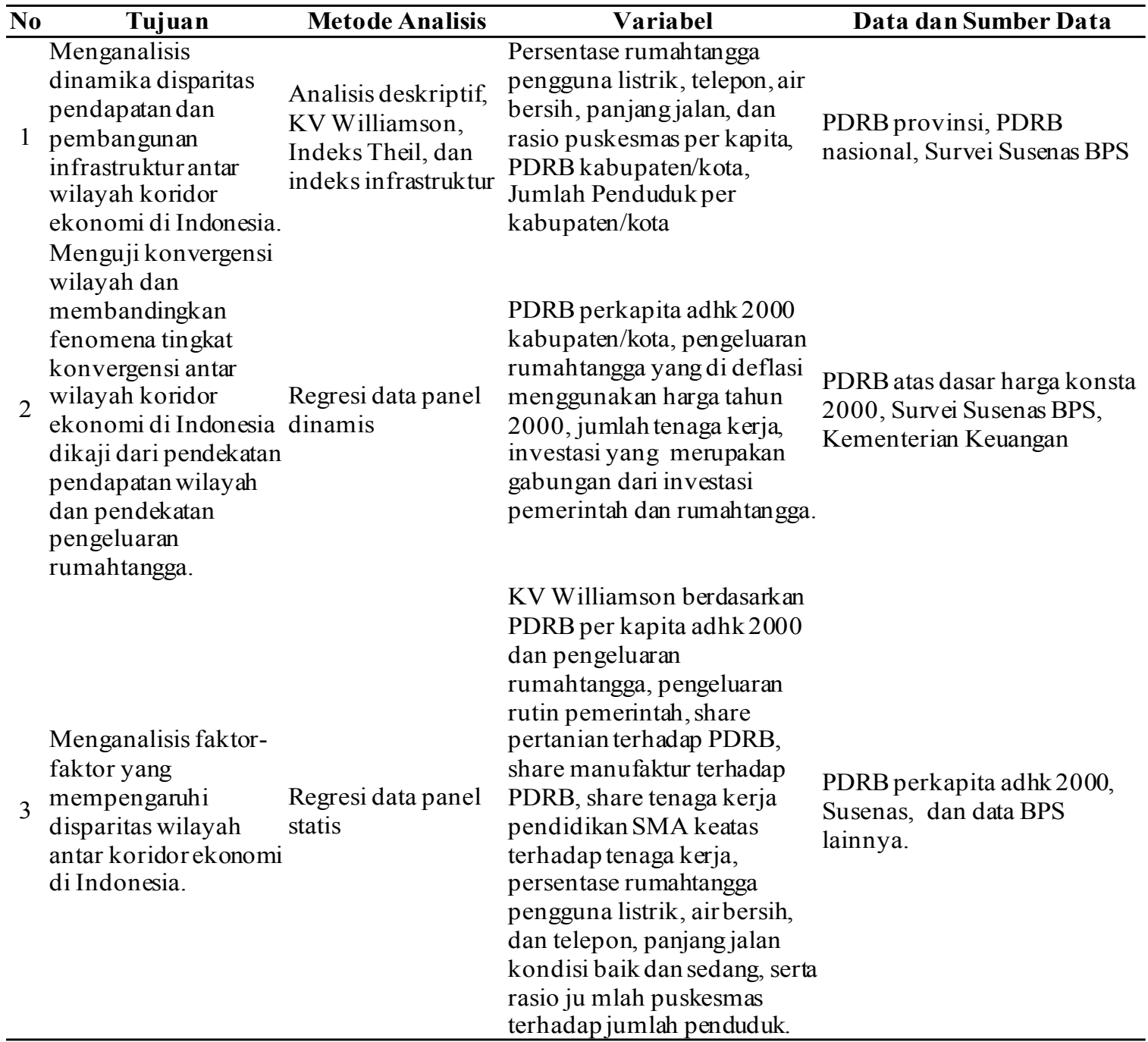

\section{METODE PENELITIAN}

Data yang digunakan dalam penelitian ini merupakan data sekunder yang bersumber dari Badan Pusat Statistik (BPS), Kementrian Keuangan, BKPM dan data-data pendukung lainnya yang relevan. Data-data yang diperlukan adalah PDRB perkapita, pengeluaran rumahtangga perkapita, investasi, pajak, pengeluaran rutin pemerintah, tenaga kerja, share pertanian terhadap PDRB, share manufaktur terhadap PDRB, share tenaga kerja berpendidikan SMA keatas terhadap jumlah tenaga kerja, persentase rumahtangga pengguna listrik, air bersih, dan telepon, rasio jumlah puskesmas terhadap penduduk, dan panjang jalan kondisi baik dan sedang. Jenis data yang digunakan adalah data panel gabungan dari time series dan cross section. Data time series dari tahun 2006-2010. Obyeknya adalah kabupaten/kota di Indonesia.

Metode analisis deskriptif digunakan untuk menganalisis dinamika perkembangan disparitas pendapatan dan pembangunan infrastruktur antar wilayah koridor ekonomi di Indonesia. Analisis inferensia dengan menggunakan data panel dinamis dengan estimasi FD-GMM untuk menguji konvergensi pendapatan wilayah dengan pendekatan PDRB dan pengeluaran rumah tangga, dan data panel statis untuk menganalisis faktor-faktor yang mempengaruhi disparitas wilayah. 
Model yang digunakan dalam penelitian ini untuk menguji konvergensi dilakukan dengan mengasumsikan fungsi Cobb ouglass constant return to scale dengan output $(\mathrm{Y})$ dan tiga input, yaitu capital (K), tenaga kerja (L), dan Labour augmenting technological progress (A) dan pengacu pada penelitian Tri Wahyuni (2011).

Dalam penelitian ini ada beberapa bagian yang akan dianalisis, diantaranya yaitu : menguji konvergensi wilayah dan membandingkan fenomena tingkat konvergensi antar wilayah koridor ekonomi di Indonesia dikaji dari pendekatan pendapatan wilayah dan pendekatan pengeluaran rumah tangga.

$\ln y_{i t}=(1-\alpha) \ln y_{i, t-1}+\beta_{1} \ln i n v_{i t}+\beta_{2} \ln$ labour $_{i t}+$

Dimana yit dalam masing-masing model adalah variabel dependen yaitu:

(i) PDRB per kapita atas dasar harga konstan 2000 untuk melihat pendapatan wilayah setelah meniadakan unsur inflasi.

(ii) Pengeluaran rumah tangga per kapita yang telah dideflasi menggunakan harga tahun 2000, yang merupakan proksi untuk melihat pendapatan rumah tangga.

Proses konvergensi terjadi apabila koefisien dari $(1-\alpha)$ kurang dari satu, dengan tingkat konvergensi dinyatakan sebagai - ln (a). Adanya lag variabel dependen (y_(i,t1)) pada ruas kanan menunjukkan bahwa model yang digunakan adalah model dinamis. Variabel independen yang diteliti adalah investasi dan tenaga kerja. Variabel investasi merupakan gabungan investasi yang dilakukan pemerintah kabupaten/ kota untuk pembangunan pengeluaran untuk infrastruktur) dan investasi rumah tangga untuk perumahan (pengeluaran untuk perumahan) yang diagregatkan untuk wilayah kabupaten/kota. i adalah kabupaten/ kota di koridor tertentu, dan $\mathrm{t}$ adalah tahun pengamatan (2006-2010).

Menganalisis faktor-faktor yang mempengaruhi disparitas wilayah antar koridor ekonomi di Indonesia. h $y_{i}=\gamma+\theta_{1}$ h govexp ${ }_{i}+\theta_{2}$ h agri $i_{t}+\theta_{3}$ h manu $u_{i}+\theta_{4}$ h edu $u_{t}+$ $+\theta_{5}$ h electric $_{i}+\theta_{6}$ h water $_{i}+\theta_{7}$ h phone ${ }_{i}+\theta_{8}$ h road ${ }_{i}+\theta_{9}$ puskes $_{i}+v_{i}$

Dimana:

y :koefisien variasi Williamson, yang dihitung dengan menggunakan dua pendekatan:

(i) cvpdrb : PDRB per kapita atas dasar harga konstan 2000

(ii) cvcons :pengeluaran rumah tangga yang telah dideflasi menggunakan harga tahun 2000

govexp :pengeluaran rutin pemerintah per kapita

agri :share pertanian terhadap PDRB atas dasar harga konstan 2000

manu :share manufaktur terhadap PDRB atas dasar harga konstan 2000

edu :sharetenagakerjayangberpendidikan SMA ke atas terhadap jumlah tenaga kerja.

electric :persentase rumahtangga pengguna listrik

water :persentase rumahtangga pengguna air bersih

phone :persentase rumahtangga pengguna telepon

road :panjang jalan yang kondisinya baik dan sedang, baik jalan negara, jalan provinsi, maupun jalan kabupaten/ kota yang berada di masing-masing provinsi per kapita

puskes :rasio puskesmas terhadap jumlah penduduk

i :provinsi di setiap koridor

t $\quad$ :tahun penelitian, yaitu dari 2006-2010.

\section{HASIL DAN PEMBAHASAN}

\section{DinamikaDisparitas Wilayahdan Pembangunan Infrastruktur}

Pembangunan wilayah merupakan sub sistem dari pembangunan koridor ekonomi dan provinsi dan merupakan bagian yang tak dapat dipisahkan dari pembangunan nasional. Pembangunan yang dilaksanakan lebih mencerminkan aspirasi, potensi, masalah dan 
kebutuhan masyarakat yang bersangkutan dengan pembangunan wilayah. Pelaksanaan pembangunan ekonomi di masing-masing kabupaten/kota telah menghasilkan pencapaian yang berbeda-beda. Hal ini berhubungan dengan keunggulan komparatif yang dimiliki masing-masing kabupaten/kota serta potensi perekonomiannya.

Tren dinamika disparitas kabupaten/ kota di Indonesia selama periode 20062010 mengalami kecenderungan menurun, baik dihitung dengan pendekatan PDRB maupun pengeluaran rumah tangga. Namun disparitas wilayah kabupaten/kota di Indonesia masih tinggi. Hasil penghitungan koefisien variasi Williamson dengan pendekatan PDRB menunjukkan bahwa disparitas kabupaten/kota di Indonesia masih tinggi, berada pada kisaran 0,75 sampai dengan 0,77 selama periode penelitian, dimana disparitas di dalam koridor ekonomi lebih tinggi dibandingkan disparitas antar koridor ekonomi. Tren disparitas kabupaten/kota di masing-masing koridor juga mengalami kecenderungan menurun sama halnya dengan Indonesia, dimana disparitas kabupaten/kota yang terjadi Koridor Jawa, serta Koridor Papua-Kep Maluku lebih tinggi dibandingkan Koridor Sumatera, Kalimantan, Sulawesi, dan Bali-Nusa Tenggara (Tabel 2). Keadaan ini menurut Capello (2007) bahwa analisis pembangunan wilayah yang mensyaratkan dua hal, yaitu pertumbuhan absolut yang menunjukkan kemampuan sumber daya yang potensial di wilayah tersebut dan pertumbuhan relatif antar wilayah yang digunakan untuk menginterpretasikan disparitas wilayah dan kemungkinan dari konvergensi pada tingkat pertumbuhannya atau pendapatan rata-ratanya.

Disparitas paling tinggi pendekatan PDRB terjadi di korodor ekonomi Papua-Kep Maluku yaitu pada kisaran antara 0,91 sampai 0,96 . Angka ini masih sangat tinggi disparitas pendapatan di koridor ekonomi Papua Kep Maluku dikarenakan di koridor tersebut masih dalam tahap awal pembangunan dimana masih mengejar pertumbuhan ekonomi sehingga disparitas masih tinggi. Hal ini dikarenakan adanya kesenjangan yang tinggi antar kabupaten/kota di koridor Papua-Kep. Maluku dalam hal pendapatan wilayah. Jika dilihat dari PDRB per kapita paling tinggi terjadi di kabupaten Mimika dengan PDRB per kapita sebesar 324.716 miliar rupiah, namun disisi lain terdapat pendapatan wilayah yang sangat jauh kesenjangannya yaitu Kabupaten Nduga dengan PDRB per kapita hanya sebesar 2.016 miliar rupiah. Namun demikian, angka tersebut terus mengalami penurunan hingga tahun 2010. Disparitas yang tertinggi setelah koridor ekonomi Papua-Kep. Maluku adalah koridor ekonomi Jawa, dimana koefisien variasi Williamson berada pada kisaran antara 0,88 sampai dengan 0,91, artinya pendapatan antar wilayah kabupaten/kota di koridor ekonomi Jawa masih sangat timpang. Hal ini disebabkan terdapat kabupaten/kota yang mempunyai PDRB per kapita terlalu tinggi yaitu Kota Jakarta Pusat sebesar 251.814 miliar rupiah, namun ditemukan juga wilayah yang mempunyai PDRB per kapita sangat rendah yaitu Kabupaten Grobogan sebesar 4.966 miliar rupiah. Keadaan inilah yang membuat tingkat disparitas di koridor Jawa masih tinggi, namun demikian angka ini mengalami kecenderungan menurun selama periode penelitian.

Tabel 2 . Koefisien Variasi Williamson Wilayah-wilayah Koridor Ekonomi di Indonesia, Tahun 2006-2010

\begin{tabular}{lccccccccccc}
\hline \multirow{2}{*}{$\begin{array}{c}\text { Wilayah } \\
\text { Koridor Ekonomi }\end{array}$} & \multicolumn{4}{c}{ Pendekatan PDRB } & \multicolumn{4}{c}{ Pendekatan Pengeluaran Rumah } \\
\cline { 2 - 12 } & 2006 & 2007 & 2008 & 2009 & 2010 & 2006 & 2007 & 2008 & 2009 & 2010 \\
\hline Indonesia & 0,77 & 0,76 & 0,76 & 0,76 & 0,75 & 0,32 & 0,31 & 0,34 & 0,31 & 0,30 \\
\hline 1. Sumatera & 0,51 & 0,50 & 0,50 & 0,50 & 0,50 & 0,28 & 0,27 & 0,28 & 0,27 & 0,27 \\
2. Jawa & 0,91 & 0,90 & 0,89 & 0,89 & 0,88 & 0,33 & 0,32 & 0,34 & 0,31 & 0,30 \\
3. Kalimantan & 0,50 & 0,49 & 0,49 & 0,49 & 0,48 & 0,26 & 0,26 & 0,28 & 0,26 & 0,25 \\
4. Sulawesi & 0,38 & 0,36 & 0,35 & 0,33 & 0,32 & 0,23 & 0,22 & 0,24 & 0,19 & 0,17 \\
5. Bali-Nusa Tenggara & 0,35 & 0,35 & 0,34 & 0,33 & 0,33 & 0,21 & 0,20 & 0,22 & 0,19 & 0,18 \\
6. Papua-Kep-Maluku & 0,96 & 0,95 & 0,94 & 0,93 & 0,91 & 0,38 & 0,37 & 0,38 & 0,35 & 0,33 \\
\hline
\end{tabular}


Tingkat disparitas yang dihitung dengan pendekatan rumah tangga lebih banyak dipengaruhi keadaan perekonomian dan harga barang-barang kebutuhan pokok, meskipun dalam penghitungan inflasi sudah dihilangkan dengan mendeflasi data berdasarkan harga tahun 2000. Hal ini dibuktikan dengan adanya peningkatan disparitas pada tahun 2008. Krisis ekonomi dunia yang terjadi pada tahun 2008 berdampak terhadap peningkatan disparitas yang dapat menggambarkan tingkat kesejahteraan masyarakat di Indonesia dan wilayah-wilayah koridor ekonomi.

Berdasarkan Indeks Theil tahun 20062010, terlihat bahwa tingkat pemerataan aktifitas perekonomian yang tercermin dari nilai PDRB antar kabupaten/kota dalam koridor ekonomi masih rendah, namun perkembangannya menunjukkan kondisi yang lebih baik yaitu pada range 0,609 dan 0,587 . Perkembangan disparitas pendapatan wilayah menunjukkan penurunan dari tahun 2006 sebesar 0,746 turun menjadi 0,717 pada tahun 2010 (Gambar 1). Disparitas antar koridor (berada pada range 0,518 dan 0,512 ) lebih rendah dibandingkan disparitas dalam koridor ekonomi.

Gambar 1. Disparitas Antar dan Intra Koridor Ekonomi di Indonesia, 2006-2010

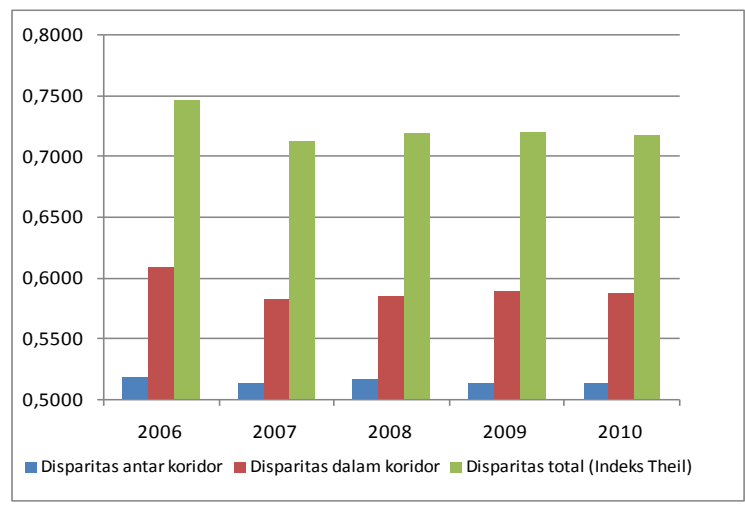

Dinamika pembangunan infrastruktur antar koridor ekonomi di Indonesia selama periode tahun 2006-2010 secara umum terus mengalami peningkatan. Peningkatan fasilitas infrastruktur yang terjadi masih belum sesuai dengan yang diharapkan, karena peningkatan terhadap kebutuhan infrastruktur secara umum juga terus meningkat. Indeks infrastruktur yang tertinggi terjadi di Koridor Jawa dan Sumatera, sedangkan yang terendah terjadi di Koridor Papua-Kep. Maluku (Tabel 3).
Tabel 3. Hasil Penghitungan Indeks Infastruktur dan Peringkatnya antar Koridor Ekonomi di Indonesia, Tahun 2006 dan 2010

\begin{tabular}{rlllllll}
\hline \multirow{2}{*}{ No } & \multicolumn{1}{c}{ Wilayah } & \multicolumn{3}{c}{2006} & \multicolumn{4}{c}{2010} \\
\cline { 3 - 8 } & Koridor Ekonomi & Indeks & Peringkat & Kategori & Indeks & Peringkat & Kategori \\
\hline 1 & Sumatera & 56,95 & 2 & tinggi & 60,16 & 2 & tinggi \\
2 & Jawa & 86,00 & 1 & tinggi & 86,00 & 1 & tinggi \\
3 & Kalimantan & 51,42 & 5 & tinggi & 51,42 & 4 & tinggi \\
4 & Sulawesi & 55,25 & 3 & tinggi & 55,25 & 3 & tinggi \\
5 & Bali-Nusa Tenggara & 52,69 & 4 & tinggi & 49,69 & 5 & sedang \\
6 & Papua-Kep. Maluku & 46,96 & 6 & sedang & 46,96 & 6 & sedang \\
\hline
\end{tabular}

\section{Konvergensi Wilayah}

Estimasi konvergensi Indonesia dilakukan dengan menggunakan dua pendekatan pada variabel dependennya, yaitu pendekatan PDRB dan pengeluaran rumah tangga. Perbandingan ini dilakukan untuk melihat apakah ada perbedaan pertumbuhan ekonomi secara makro yaitu di level wilayah kabupaten/kota dan secara mikro yaitu level rumah tangga. Tingginya pendapatan wilayah tidak secara otomatis menyebabkan tingginya kesejahteraan masyarakatnya karena dimungkinkan pendapatan di wilayah tersebut dimiliki oleh orang asing atau dengan kata lain hasil produksi dibawa ke wilayah lain dan digunakan untuk kesejahteraan masyarakat lain.

Proses konvergensi pendapatan dapat dilihat dari koefisien yt-1 pada estimasi konvergensi PDRB per kapita lebih dari 1, yang menunjukkan bahwa konvergensi tidak terjadi di Indonesia (pendapatan kabupaten/ kota di Indonesia divergen) dengan metode panel dinamis FD-GMM. Peghitungan konvergensi PDRB per kapita kabupaten/kota di Indonesia berbeda dengan hasil penelitian Firdaus dan Yusop (2009) yang menghitung konvergensi pendapatan antar provinsi di Indonesia dalam kurun waktu 1983-2003 (proses konvergensi terjadi di Indonesia dengan FD-GMM, namun kecepatan konvergensi hanya 0,29 persen relatif lebih lambat dibanding penelitian di negara berkembang lainnya). Sedangkan penelitian ini, pada level kabupaten/kota di Indonesia justru tidak terjadi. Fenomena ini disebabkan adanya pusat-pusat industri di kota-kota besar, yang menyebabkan perbedaan tingkat 
pembangunan yang semakin lebar. Selain itu wilayah penelitian yang berada pada Daerah Tingkat II atau kabupaten/kota menyebabkan interaksi ekonomi dan ketergantungan spasial yang tinggi antar wilayah mempunyai potensi menyesatkan hasil penelitian jika tidak memperhatikan efek spasial (spatial filtering) dalam model data panel dinamis (Badinger, et al., 2002)

Tingkat konvergensi dengan pendekatan pengeluaran rumah tangga, terjadi konvergensi pengeluaran rumah tangga di antara kabupaten/kota di Indonesia. Tingkat konvergensi terjadi di semua koridor di Indonesia, baik dengan pendekatan PDRB maupun pendekatan pengeluaran rumah tangga. Tingkat konvergensi dpendekatan PDRB tertinggiterjadi di Koridor Kalimantan dan terendah di Koridor Sulawesi, sedangkan konvergensi pendekatan pengeluaran rumah tangga tertinggi terjadi di Koridor Jawa dan yang terendah di Koridor Sulawesi. Sementara secara keseluruhan, konvergensi pendekatan pengeluaran rumah tangga lebih tinggi dibandingkan pendekatan PDRB, dengan tingkat konvergensi tertinggi terjadi di Koridor Jawa.

Tabel 4 . Estimasi Tingkat Konvergensi Wilayah-wilayah Koridor Ekonomi di Indonesia dengan Model Data Panel Dinamis FD-GMM

\begin{tabular}{|c|c|c|}
\hline Uraian & Koefisien yt-1 & Implied $\lambda$ \\
\hline \multicolumn{3}{|l|}{ Pendekatan PDRB } \\
\hline Indonesia & 1,0512 & NA \\
\hline Sumatera & 0,6609 & 41,4118 \\
\hline Jawa & 0,9232 & 7,9896 \\
\hline Kalimantan & 0,3625 & 101,4740 \\
\hline Sulawesi & 0,9626 & 3,8156 \\
\hline Bali-Nusa Tenggara & 0,5169 & 65,9817 \\
\hline Papua-Kep. Maluku & 0,7485 & 53,5289 \\
\hline \multicolumn{3}{|l|}{ Pendekatan Pengeluaran Rumah Tangga } \\
\hline Indonesia & 0,6699 & 40,0572 \\
\hline Sumatera & 0,0971 & 233,2314 \\
\hline Jawa & 0,0678 & 269,1193 \\
\hline Kalimantan & 0,1728 & 175,5620 \\
\hline Sulawesi & 0,5162 & 66,1208 \\
\hline Bali-Nusa Tenggara & 0,2109 & 155,6382 \\
\hline Papua-Kep. Maluku & 0,0824 & 249,5953 \\
\hline
\end{tabular}

Tingkat konvergensi pengeluaran rumah tangga mencapai nilai yang tinggi karena pendekatan ini hanya melihat konvergensi dari pelaku ekonomi rumah tangga, berbeda dengan konvergensi PDRB yang melibatkan semua pelaku ekonomi, baik rumah tangga, swasta, maupun pemerintah. Aktivitas ekonomi yang dilakukan juga berbeda, tidak hanya konsumsi seperti pendekatan pengeluaran rumah tangga, namun juga investasi, baik yang dilakukan perusahaan swasta maupun pemerintah. Perbandingan tingkat konvergensi ini menunjukkan bahwa tingkat pembangunan wilayah yang sama akan dicapai dalam kurun waktu yang lebih lama dibandingkan dengan kesamaan daya beli masyarakat. Perbandingan tingkat konvergensi kabupaten/kota di beberapa koridor di Indonesia dapat terlihat pada Tabel 4.

\section{Faktor-faktor yang Mempengaruhi Disparitas Wilayah}

Estimasi faktor-faktor yang mempengaruhi disparitas wilayah di beberapa koridor dan Indonesia dilakukan dengan model data panel statis. Model yang terpilih pada pendekatan PDRB untuk Indonesia adalah random effect, sedangkan pada pendekatan pengeluaran rumah tangga adalah fixed effect. Faktor-faktor yang mempengaruhi disparitas pendapatan antar wilayah antar provinsi di Indonesia pendekatan PDRB adalah share tenaga kerja berpendidikan SMA keatas, dan infrastruktur telepon secara negatif dengan elastisitas 0,32 dan 0,23. Jika kontribusi tenaga kerja berpendidikan SMA keatas meningkat 1 persen, maka disparitas akan menurun sebesar 0,32 persen, ceteris paribus. Arah yang sama juga pada variabel infrastruktur telepon yang diproksi dengan persentase rumah tangga pengguna telepon. Jika share rumah tangga pengguna telepon meningkat sebesar 1 persen, maka disparitas pendapatan menurun sebesar 0,23 persen, ceteris paribus. Disparitas pengeluaran rumah tangga dipengaruhi oleh infrastruktur air bersih dan telepon secara negatif, infrastruktur jalan dan infrastruktur 
puskesmas secara positif. Koridor Sumatera pendekatan PDRB dan pengeluaran rumah tangga dipengaruhi oleh infrastruktur telepon secara negatif.

Koridor Jawa pendekatan PDRB dipengaruhi oleh share sektor manufaktur secara positif, dan infrastruktur jalan secara positif, sedangkan pendekatan pengeluaran rumah tangga dipengaruhi oleh infrastruktur jalan secara positif. Besarnya pengaruh faktorfaktor tersebut dapat dilihat dari besarnya koefisien regresi yang dimilikinya dan arah dari nilai koefisien tersebut (positif atau negatif). Semakin besar nilai koefisiennya, semakin besar pula pengaruh variabel tersebut sesuai dengan arah nilainya, begitu juga sebaliknya. Variabel yang memiliki koefisien bernilai positif menunjukkan bahwa peningkatan variabel tersebut akan dapat meningkatkan disparitas, sedangkan variabel yang memiliki koefisien negatif akan mempengaruhi penurunan disparitas.

Pembangunan infrastruktur jalan dengan kondisi baik dan sedang banyak digunakan dan dimanfaatkan atau didominasi oleh industri dan bisnis dari wilayah lain atau ke wilayah lain, sedangkan pemanfaatan jalan oleh masyarakat atau rumah tangga di wilayah setempat kurang dimanfaatkan karena kondisi pembangunan jalan bukan berada di wilayah dimana yang selalu dilalui untuk dimanfaatkan oleh masyarakat setempat. Dengan demikian, maka pembangunan infrastruktur jalan tersebut meningkatkan ketidakmerataan pembangunan wilayah. Koridor Kalimantan pendekatan PDRB dan pengeluaran rumah tangga dipengaruhi oleh infrastruktur listrik secara positif. Koridor Sulawesi pendekatan PDRB dipengaruhi oleh shate tenaga kerja berpendidikan SMA keatas secara negatife, sedangkan pendekatan pengeluaran rumah tangga dipengaruhi oleh infrastruktur telepon secara negatif. Koridor Bali-Nusa Tenggara dan Papua-Kep.Maluku pendekatan PDRB dan pengeluaran rumah tangga dipengaruhi oleh share pengeluaran rutin pemerintah secara negatif.

\section{SIMPULAN}

Disparitas kabupaten/kota di Indonesia selama periode 2006-2010 masih tinggi, walaupun sedikit mengalami kecenderungan menurun baik dengan pendekatan PDRB maupun pengeluaran rumah tangga. Disparitas kabupaten/kota di masing-masing koridor juga sedikit mengalami penurunan, dimana disparitas kabupaten/kota Koridor Jawa dan Papua-Kep Malukulebih tinggi dibandingkan Koridor Sumatera, Kalimantan, Sulawesi, dan Bali-Nusa Tenggara. Pembangunan infrastruktur di Indonesia meningkat, keadaan ini juga terjadi di semua koridor ekonomi dalam MP3EI di Indonesia. Indeks infrastruktur yang tertinggi terjadi di Koridor Ekonomi Jawa dan Sumatera, sedangkan yang terendah terjadi di Koridor Papua-Kep. Maluku.

Konvergensi pendekatan PDRB wilayah kabupaten/kota di Indonesia tidak terjadi (divergen), namun konvergensi pendekatan pengeluaran rumah tangga terjadi konvergensi. Konvergensi terjadi di semua koridor di Indonesia, baik dengan pendekatan PDRB maupun pendekatan pengeluaran rumah tangga. Tingkat konvergensi pendekatan $\mathrm{PDRB}$ tertinggi terjadi di Koridor Kalimantan dan terendah di Koridor Sulawesi, sedangkan konvergensi pendekatan pengeluaran rumah tangga tertinggi terjadi di Koridor Jawa dan yang terendah di Koridor Sulawesi. Konvergensi pendekatan pengeluaran rumah tangga lebih tinggi dibandingkan pendekatan PDRB.

Faktor-faktor yang mempengaruhi disparitas pendapatan antar wilayah antar provinsi di Indonesia pendekatan PDRB adalah share tenaga kerja berpendidikan SMA keatas, dan infrastruktur telepon secara negatif. Disparitas pengeluaran rumah tangga dipengaruhi oleh infrastruktur air bersih dan telepon secara negatif, infrastruktur jalan dan infrastruktur puskesmas secara positif. Kecenderungan di kawasan barat Indonesia, penurunan disparitas lebih dipengaruhi oleh infrastruktur telepon, sedangkan kawasan timur Indonesia dipengaruhi oleh pengeluaran rutin pemerintah dan infrastruktur telepon. 


\section{DAFTAR PUSTAKA}

Badinger, H., W. G. Muller, and G. Tondl. 2002. Regional Convergence in the European Union (1985-1999). IEF Working Papers 47:7-17.

Capello, R. 2007. Regional Economics. Routledge, New York.

Firdaus, M. and Z. Yusop. 2009. Dynamic Analysis of Regional Convergence in Indonesia. International Journal of Economic and Manajemen, Volume 3 No.1, pages 73-86.
Ralhan, M. dan A. Dayanandan. 2005. Convergence of Income Among Provinces in Canada - An Application of GMM Estimation. Econometrics Working Paper EWP 0502:13-21

Rumayya, W. W. dan E. A. Landiyanto. 2005. Growth in East Java: Convergence or Divergence?. Econ WPA 0508: 15-16.

Wahyuni, K.T. 2011. Konvergensi dan Faktor-faktor yang Memengaruhi Ketimpangan Wilayah Kabupaten/ Kota di Pulau Jawa [tesis]. Program Pascasarjana IPB. Bogor. 